\title{
Presencia e importancia de la mujer en el Musnad de Ibn Marzūq al-Tilimsānī
}

\section{Presence and Importance of Women in the Musnad by Ibn Marzūq al-Tilimsānī}

\author{
Bárbara BOLOIX GALLARDO \\ Universidad de Granada \\ bboloix@ugr.es
}

Recibido: 29 de enero de 2015

Aceptado: 15 de mayo de 2015

\section{RESUMEN}

El Musnad del cronista Muhammad Ibn Marzūq (m. 781/1379) constituye una de las fuentes meriníes más ricas y personales al estar consagrada a ensalzar las virtudes del emir Abū 1-Ḥasan (731749/1331-1348). El gran valor de esta obra radica en la enorme variedad de su contenido, que abarca múltiples facetas de la vida del reino meriní. El presente artículo tratará, desde un enfoque crítico, uno de los temas menos explorados de esta fuente: la presencia de la mujer en la misma, así como el papel que ésta desempeñó en distintos ámbitos de la sociedad magrebí, según se desprende de las numerosas referencias femeninas ofrecidas a lo largo del Musnad, que serán extraídas y analizadas.

Palabras clave: mujeres, reino meriní, Magreb, Musnad, Ibn Marzūq, siglo XIV.

\begin{abstract}
The Musnad by the chronicler Muhammad Ibn Marzūq (d. 781/1379) is considered one of the richest and more personal Merinid sources, as it was devoted to extol the virtues of the emir Abu l-Hasan (731-749/1331-1348). The major value of this work resides in the wide variety of its content, which covers multiple facets of the Merinid kingdom. This article aims to tackle one of the less explored aspects of this source from a critical approach: the presence of women and the role played by them within the Maghribi society, according to the numerous feminine references offered throughout the Musnad, which will be both extracted and analyzed.
\end{abstract}

Keywords: women, Merinid Kingdom, Maghreb, Musnad, Ibn Marzūq, $14^{\text {th }}$ century.

SUMARIO. 1. Introducción: el Musnad, una fuente plural, 2. Las mujeres santas del Islam, espejos de las virtudes de Abū 1-Ḥasan, 3. La relación de Abu 1-Ḥasan con el elemento femenino: del origen materno a la práctica matrimonial. 4, Otras referencias femeninas en el Musnad, 5. Conclusión. 


\section{INTRODUCCIÓN: EL MUSNAD, UNA FUENTE PLURAL}

Son muchos y muy interesantes los estudios que, hasta la fecha, han ahondado desde distintas perspectivas en el contenido de la obra Al-Musnad al-ṣahĭh al-hasan fì ma'ātir mawlā-nā Abì l-Hasan ("Tradición auténtica y hermosa de los memorables hechos de Abū 1-Ḥasan")', debida al cálamo de Abū 'Abd Allāh Muhammad Ibn Marzūq al-Tilimsānī (m. 781/1379); una fuente que constituye una auténtica joya historiográfica a los ojos de aquellos especialistas dedicados tanto al estudio del Magreb como de al-Andalus durante la Edad Media. A pesar de los años trascurridos desde que el manuscrito de esta crónica fuese rescatado, editado y traducido del árabe al castellano por la profesora $\mathrm{M}^{\mathrm{a}}$ Jesús Viguera Molins en su Tesis Doctoral ${ }^{2}$, el Musnad continúa siendo hoy día un inagotable manantial de datos que nos sigue revelando curiosísimos aspectos de la dinastía y de la sociedad meriníes del siglo XIV en tiempos del sultán Abū l-Ḥasan 'Alī (731-749/1331-1348).

El mayor mérito de esta fuente, ya resaltado por cuantos la han manejado en sus investigaciones, radica en la posición privilegiada de su autor con respecto al emir historiado, a cuyo servicio trabajó durante doce años, "en el regazo de cuya crianza" el autor creció, como él mismo expresa agradecido en el arranque de su obra ${ }^{3}$. Este hecho convierte al Musnad en la mejor atalaya desde la que divisar las dichas y las desgracias acaecidas tanto en el ámbito público del gobierno de Abū 1-Ḥasan como en el más íntimo seno de su casa. Y es que esta obra es unauténtico testigo presencial del gobierno de este sultán meriní, considerado "el soberano culminante de su dinastía". A ello hay que añadir la coyuntura de que fuese compuesta veinte años después de haber fallecido este sultán, a modo de "canonisation posthume", con la que el autor pretendía ganarse el favor de su hijo y cuarto sucesor, el sultán Abū Fāris (767-774/1366-1372).

Sin embargo, no debemos olvidar la necesidad de despojar la información suministrada por esta fuente del subjetivismo, y hasta del servilismo, propios de su

\footnotetext{
${ }^{1}$ Para la elaboración del presente trabajo han sido empleados tanto la edición árabe como la excelente traducción al castellano que de este texto realizó la profesora $\mathrm{M}^{\mathrm{a}}$ Jesús Viguera: IBN MARZŪQ, Muḥammad, Al-Musnad al-Sahịh li-Ibn Marzūq. Ed. Ma Jesús Viguera Molins con prefacio de M. Bouayed, Argel 1981 (reimpreso en Argel: 2007; reimpr. Rabat: Dār al-Amān, 2013); VIGUERA MOLINS, M ${ }^{\mathrm{a}}$ Jesús, El Musnad: hechos memorables de Abu l-Hasan, sultán de los Benimerines. Estudio, traducción, anotación e indices anotados por María Jesús Viguera, Madrid 1977.

${ }^{2}$ Tesis Doctoral dirigida por el Dr. Fernando de la Granja Santamaría y defendida en la Universidad Complutense de Madrid en 1973.

${ }^{3}$ IBN MARZŪQ, Muḥammad, Musnad, 92; trad. VIGUERA, 81.

${ }^{4}$ VIGUERA MOLINS, M ${ }^{\mathrm{a}}$ Jesús, "La exaltación biográfica de Abū 1-Hasan, sultán de los Benimerines", en Biografías y género biográfico en el Occidente islámico, $\mathrm{M}^{\mathrm{a}}$ Luisa Ávila y Manuela Marín (eds.) (1997), 403. Para la biografía de este soberano, véanse las referencias expuestas por la citada autora en la página 403 del recién referido artículo, nota al pie 1.

${ }^{5}$ GUBERT, Serge, "Graver, exposer, déclamer: La legitimité recomposée des supports discursifs du politique à l'époque merinide (XIII ${ }^{\text {ème }}-\mathrm{XV}^{\text {ème }}$ siècles)", en Documentos y manuscritos árabes de Occidente musulmán medieval, Nuria Martínez de Castilla (ed.) (2011),179.
} 
condición de crónica dinástica. Independientemente de la veracidad de las bondades que engalanaban a su máximo protagonista, el Musnad es, ante todo, un ejemplo de "biografía ejemplar" o "laudatoria" "producida en el entorno real o cortesano, con el objetivo principal de legitimar el «buen Poder»" ". Dicho recorrido, biográfico y personal, sirve pues de principal eje vertebrador de distintos aspectos (histórico, político, religioso, social, genealógico, antropológico, costumbrista, moral) que, en forma de anécdotas, acompañan paralelamente su desarrollo con un solo fin: trazar el perfil biográfico del sultán Abū l-Ḥasan.

De todos estos ámbitos, la mayoría de ellos analizados por la Dra. Viguera, principal conocedora de esta obra', tal vez el menos explorado haya sido el de la presencia femenina en el Musnad, la cual salpica de frecuentes anécdotas el contenido de sus páginas ${ }^{10}$. A lo largo de los cincuenta y cinco capítulos lo integran, junto a su introducción y su epílogo, son tan numerosos como curiosos los guiños que Ibn Marzūq hace al papel político y social ejercido por la mujer meriní en tiempos de dicho emir. Este ámbito es cubierto por el autor de una manera plural, pues el tema femenino en esta obra no solamente abarca el contexto dinástico señalado sino también otros colectivos étnicos, confesionales, sociales y políticos distintos al meriní. En este último sentido cabe señalar cómo esta obra también contempla las formaciones cercanas - tales como el Reino Zayyāní de Tremecén, el Ḥafșí de Túnez o el frontero Reino Nazarí de Granada-, todo lo cual resulta en una visión muy rica de este aspecto, siendo un claro indicador de la gran importancia que la mujer tuvo tanto en la cúspide de la pirámide social magrebí del siglo XIV (la corte meriní) como en su base misma (el pueblo llano).

${ }^{6}$ VIGUERA MOLINS, Ma Jesús, "La exaltación biográfica de Abū l-Ḥasan”, 406; VIGUERA MOLINS, Ma Jesús, “'Vida ejemplar' de Abū l-Hasan, sultán de los Benimerines”, Erebea, 3 (2013), 49.

${ }^{7}$ MANZANO RODRÍGUEZ, Miguel Ángel, "Biografías y poder político: la imagen de los sultanes magrebíes en la baja Edad Media", en Biografías y género biográfico, 249 y 250.

${ }^{8}$ VIGUERA MOLINS, M ${ }^{\text {a }}$ Jesús, "Planteamientos sobre Historia de al-Andalus", en El saber en al-Andalus. Textos y Estudios II, Julia Carabaza Bravo y Aly Tawfik Essawi (eds.), (1999), 122.

${ }^{9}$ Véanse algunos de los numerosos artículos que desgranan distintos aspectos de esta obra debidos a VIGUERA MOLINS, M ${ }^{\mathrm{a}}$ Jesús: "El Musnad de Ibn Marzūq", Miscelánea Comillas, XXXII/60 (1974), 101-126; “Au sujet du 'Musnad' d'Ibn Marzūq", Arabica, XXIII (1976), 266-274; "Ajbār Ifrīqiya fī l-Musnad li-Ibn Marzūq", Cahiers de Tunisie, XXVI/n ${ }^{\text {os } 103-104 ~(1978), ~ 61-87 ; ~ " I b n ~}$ Marzūq según Ibn al-Jațīb", Revue de la Faculté de Lettres de Tetouan, II (1986-1987), 220-229; "Religión y política de los Benimerines", 'Ilu. Revista de Ciencias de las Religiones.Actas I Simposio Nacional de Ciencias de las Religiones (1995), 285-288; “Al-Musnad, manuscrito en Rabat y en El Escorial”, en Manuscritos árabes en Marruecos y en España: espacios compartidos, M. Ammadi, F. Vidal-Castro y M. J. Viguera Molins (eds.) (2013), 175-179; "Le manuscrit d'al-Musnad d'Ibn Marzuq, conservé à la Bibliothèque de l'Escurial (ms. arabe 1666)", en Catalogue de l'exposition: Le Maroc médiéval (2014).

${ }^{10}$ Sobre este tema según ésta y otras fuentes, véase BOLOIX GALLARDO, Bárbara, "Fès, point de rencontre entre sultanes nasrides et mérinides", en Fes, 1200 ans d'Histoire, Jerónimo Páez (ed.), Granada, 2015, 300-316. 
Este fenómeno, también frecuente en otros órdenes sociales coetáneos, pudo ser algo más acusado en este especial contexto, debido en parte a las peculiaridades propias de la sociedad beréber o amazigh. Aunque es cierto que esta última acabó compartiendo con la árabe ciertos patrones sociales -fundamentalmente el Islam como elemento de cohesión-, también lo es que, desde siempre, se distinguió de ésta en ciertos aspectos etnográficos, como el modus vivendi de sus mujeres ${ }^{11}$. Así lo afirma Ch. Pellat, para quien la mujer beréber se ha caracterizado por gozar de un margen de libertad mayor que la árabe ${ }^{12}$. Georges Marcy ${ }^{13}$ incidió también en los vestigios existentes en la sociedad beréber actual de un sistema de filiación maternal propio de las raíces históricas de esta cultura. Marcy no solamente argumenta la mayor preeminencia de la familia materna sobre la paterna, sino que también identifica costumbres beréberes fundadas sobre un antiguo régimen de parentesco uterino conservadas en el Magreb central -entre ellas, la existencia de un sistema de sucesión dinástica no "sálica" que contemplaba el derecho a reinar de las mujeres, la adscripción de los hijos a la formación tribal de la madre o el derecho de ésta tanto a imponerles nombres de sus propios parientes paternos o de decidir sobre la paternidad de sus vástagos-.

Estas antiguas licencias tal vez se debiesen al hábitat rural propio de esta civilización; no olvidemos que la beréber ha constituido siempre una población agraria cuya organización social ha estado basada en reales o ficticios lazos de sangre sin notables diferencias sociales. El núcleo de su sociedad la ha constituido el hogar, como núcleo humano, o el poblado como conjunto de hogares, unidad social y política denominada entre los nómadas "douar" (dawwār) y habitada por descendientes de la misma rama familiar paterna ${ }^{14}$. Dichos parámetros concedieron, quizás, un mayor peso al matriarcado dentro de la sociedad beréber, concepto que no debemos confundir con la existencia de una estructura matrilineal. De hecho, Teresa Garulo ${ }^{15}$

\footnotetext{
${ }^{11}$ Sobre la sociedad beréber, véase BASSET, R.-[PELLAT, Ch], "Berbers", en Encyclopaedia of Islam, en H. A. R Gibb, J. H. Kramers, E. Lévi-Provençal y J. Schacht (eds.), (1979), vol. I, 11731187; GONZÁLEZ, Valerie, "Berbers", en Medieval Islamic Civilization. An Encyclopedia, Josef W. Meri (ed.) (2006), vol.I, 105.

${ }^{12}$ BASSET, R.-[PELLAT, Ch], "Berbers", 1179; opinión compartida por JIMÉNEZ ESTACIO, $\mathrm{M}^{\mathrm{a}}$ del Mar, "Las mujeres beréberes de al-Andalus", II Congreso Virtual sobre Historia de las mujeres, 15-31 Octubre 2010, 8, disponible en http://www.revistacodice.es/publi_virtuales/ii_congreso_mujeres/comunicaciones/JIMENEZESTACIO.pdf.

${ }^{13}$ MARCY, Georges, "Le vestiges de la parenté maternelle en droit coutumier berbère", Revue Africaine, 85 (1941), 187-211.

${ }^{14}$ BAUER Y LANDAUER, Ignacio, "La sociedad beréber", Cuadernos de Estudios Africanos, 6 (1949), 64.

${ }^{15}$ GARULO, Teresa, "Woman in Medieval Classical Arabic Poetry", en Writing the Feminine.Women in Arab Sources, Manuela Marín y Randi Deguilhem (eds.), (2002), 34.Véase también, en la misma obra colectiva, VIGUERA MOLINS, Ma Jesús, "A Borrowed Space: Andalusi and Maghribi Women in Chroniclers", 165-180.
} 
reflexionaba sobre la posibilidad de que los beréberes fueran menos reticentes que los árabes al hablar de sus mujeres en poesía.

\section{LAS MUJERES SANTAS DEL ISLAM, ESPEJOS DE LAS VIRTUDES DE ABŪ L-ḤASAN}

El Musnad fue redactado con un claro objetivo y con una principal motivación: la de servir de repertorio de las múltiples "virtudes compasivas" del sultán biografiado, Abū 1-Ḥasan, enumeración que aparece vertebrada en dos principales facetas en las que la imagen de la mujer está presente: la constatación de sus bondades personales, por un lado, y la nobleza de su origen, por otro. Comenzando por el primer ámbito, los atributos que la obra le asigna podrían resumirse bajo las rúbricas de magnanimidad, piedad, indulgencia, caridad y generosidad ${ }^{16}$, siendo un fiel reflejo de "todas las virtudes islámicas" necesarias para conformar una impecable imagen política ${ }^{17}$.

Sin embargo, estas cualidades debían ser cuidadosamente escogidas según los cánones de comportamiento definidos por el Corán y el Hadiz, una tarea a la que se entregó Ibn Marzūq, quien no sólo recurrió a los patrones vitales de Mahoma y los hombres virtuosos de su entorno, sino también al ejemplo legado por las llamadas "madres de los creyentes" (ummāhāt al-mu'mininn) del Islam y otras mujeres santas, dispuestos a modo de espejo de las virtudes de dicho soberano ${ }^{18}$.Ya en la Introducción (Muqaddima) de su obra, Ibn Marzūq hace referencia a ciertos hadices en los que el tema femenino está presente, bien en su contenido bien en la identidad de la persona responsable de su transmisión. Al primer aspecto corresponde el siguiente hadiz de 'Abd Allāh Ibn 'Umar (m. 73/693)"19: "Oí decir al enviado de Dios: «Cada uno de vosotros ha de cuidar y ser responsable de lo que está a su cargo (...) El hombre, de su familia. La mujer, de la casa de su esposo (wa-l-mar'a rã 'iyya fi bayt $z a w \hat{y} i-h \bar{a})(\ldots) »^{20}$. Son diversas las tradiciones elegidas por Ibn Marzūq para su obra cuya transmisión fue realizada por féminas vinculadas a Mahoma y, principalmente, por ' $\overline{\mathrm{A}}$ ' iša bint Abī Bakr (m. 58/678) ${ }^{21}$, conducentes a ilustrar la conducta ejemplar

${ }^{16}$ VIGUERA MOLINS, Ma Jesús, "La compasión, virtud del sultán, en el Musnad de Ibn Marzūq", en Caridad y compasión en biografías islámicas, A. Ma Carballeira Debasa (ed.) (2011), 172 y 179; VIGUERA MOLINS, Mª Jesús, “Vida ejemplar' de Abū 1-Hasan”, 60.

${ }^{17}$ VIGUERA MOLINS, Ma Jesús, "La compasión, virtud del sultán”, 175.

${ }^{18}$ Sobre las madres de los creyentes musulmanes como ejemplos virtuosos, véase el reciente trabajo de ASFARUDDIN, Asma, "Early Women Exemplars and the Construction of Gendered Space", en Harem Histories. Envisioning Places and Living Spaces (en curdiva),ed. Marilyn Booth, Durham Londres, 2010, 23-48.

${ }^{19}$ Sobre este reputado transmisor de hadices que era, a su vez, hijo del segundo califa rašìdūn'Umar b. Jațāāb, véase VECCIA VAGLIERI, L., "Abd Allāh b. 'Umar b. al-Khatțāb”, en Encyclopaedia of Islam, H. A. R. Gibb, J. H. Kramers, E. Lévi-Provençal y J. Schacht (eds.), (1979), vol. I, 53-54.

${ }^{20}$ IBN MARZŪQ, Muhammad, Musnad, 104; trad. VIGUERA, 93.

${ }^{21}$ Sobre esta importante figura, véase ABBOT, Nabia, Aishah, the Beloved of Muhammad, Chicago, 1942; BINT AL-SHĀṬI', The Wifes of the Prophet, Trad. Del árabe al inglés por Matti Moosa en 
de Abū 1-Ḥasan; sirvan de ejemplo los testimonios de 'Āi'ša con los que el autor justifica el cumplimiento del ayuno por parte del sultán ${ }^{22}$.

Junto a la presencia de las "madres de los creyentes" musulmanes en este interesante texto, existen también referencias a otras féminas que despuntaron por su santidad y devoción, al igual que el emir elogiado. Así lo refleja el caso femenino que Ibn Marzūq rescata de la tradición islámica para argumentar la gran inclinación que Abū l-Ḥasan sentía hacia la práctica de la ziyāra (es decir, de la visita tanto de los santos vivos como de las sepulturas y los mausoleos de aquéllos que ya habían muerto). Según relata nuestro autor, tras el fallecimiento del Profeta, el primer califa del Islam, Abū Bakr al-Ṣiddīq (11-13/632-634) propuso al que, más tarde, sería su sucesor al frente de la comunidad islámica (al-umma), 'Umar b. Jatțāb (1323/634-644), visitar a Umm Ayman como lo solía hacer Mahoma. Esta mujer, cuyo nombre verdadero era Baraka bint Ta'alaba b. 'Amr, era una esclava originaria de Abisinia que, desde su niñez, había servido al padre del Profeta, 'Abd Allāh, y ejercido posteriormente de nodriza del propio Mahoma, a quien cuidó y sirvió durante un largo tiempo, falleciendo durante el califato de 'Uțmān Ibn 'Affān. Por esta razón aquél la tenía en gran estima, llegando en cierta ocasión a afirmar en un hadiz "Umm Ayman es mi madre". Cuando Abū Bakr y 'Umar llegaron a su casa, Umm Ayman se echó a llorar, explicando que sus lágrimas se debían a que se había cortado la revelación del cielo y que ellos, con su presencia, la habían emocionado, al igual que hicieron los dos visitantes ${ }^{23}$.

La generosidad y el altruismo, revestidos de compasión ${ }^{24}$, eran dos cualidades que también adornaban la personalidad de Abū 1-Ḥasan y que, según el Musnad, éste compartía con las mujeres de la familia del Profeta. A este respecto, Ibn Marzūq cita una anécdota bastante significativa que toma del Sậ̄h̆, según la cual se acercó en cierta ocasión un hombre hambriento a Mahoma, pidiéndole que le diese de comer. Y, como sus esposas $(a z w \bar{a} \hat{y} u-h u)$ le dijeron no tener más alimento que agua, el Enviado de Dios tuvo que buscar a alguien que pudiera acogerlo prometiendo la piedad de Dios para con él. Un miembro de los Anșār se llevó al hombre a su casa como huésped del Profeta aunque su esposa le dijo que sólo tenían la comida para sus hijos, a lo que el Anșāin propuso que entretuviese a los niños sin cenar hasta que se durmieran y que ellos dos fingiesen comer, para que el invitado pudiese cenar del único alimento disponible; y así hicieron, ganando con su generosidad la satisfacción de Dios ${ }^{25}$.

colaboración con D. Nicholas Ranson, New Jersey, 2006, cap. 4, 55-98; WATT, W. Montgomery, " "A' isha bint Abī Bakr", en EI ${ }^{2}$, I, 307-308; SPELLBERG, D. A., Politics, Gender, and the Islamic Past: The Legacy of 'A' isha bint Abī Bakr, Nueva York, 1995.

${ }^{22}$ IBN MARZŪQ, Muhammad, Musnad, 136; trad. VIGUERA, 119 y 120.

${ }^{23}$ IBN MARZŪQ, Muḥammad, Musnad, 164; trad. VIGUERA, 143.

${ }^{24}$ VIGUERA MOLINS, Ma Jesús, "La compasión, virtud del sultán”, 171-203.

${ }^{25}$ IBN MARZŪQ, Muhammad, Musnad, 188; trad. VIGUERA, 159. 
De la esplendidez de Abū 1-Ḥasan transmite Ibn Marzūq otros gestos de los que fue, precisamente, beneficiaria una mujer de al-Andalus. Según este cronista, cuando la gente de Algeciras tuvo que abandonar la ciudad al ser tomada por los cristianos, el emir meriní le hizo una serie de donaciones en función de la situación personal de cada habitante, de los bienes que habían tenido que dejar tras de sí y del enclave en el que querían instalarse. Estas dádivas, que sumaban el valor de 35.000 dinares de oro junto con el de más de 3.000 vestidos, no sólo alcanzaron a los agricultores y funcionarios de las distintas administraciones algecireñas, sino que llegaron a favorecer hasta a "una vendedora (imrā'tu kānat sawwāqa) que iba voceando el género por las casas", cuya recomendación para recibir tal prerrogativa había escrito el propio emir de su puño y letra ${ }^{26}$. De la misma manera fue auxiliado por Abū 1-Ḥasan un combatiente de la fe meriní que había luchado contra los cristianos en Ronda y que, teniendo mujer y diez hijos, había caído en una profunda pobreza; los beneficios que le otorgó este sultán -entre los que se contaban vestidos, tierras, cabalgaduras, una casa e, incluso, criados- no sólo se hicieron extensivos a sus hijos sino también a sus hijas, pues aumentó tanto el estatus social de este caballero que "después de haber estado en la miseria se convirtió en uno de los más ricos de Ronda, cundió su fama y los más notables de la región emparentaron con él [casándose con ellas]" ${ }^{27}$.Y es que "rasgos y actos muy determinados y proyecciones legendarias agigantaron la figura [de Abū 1-Ḥasan], refinada además por varios toques de tragedia, política y personal" "28, "de modo que su vida y sus actos se elevan hasta hacerlos coincidir con esos modelos" ${ }^{" 29}$ que debían definir la figura de un soberano magrebí ante sus súbditos, algunos de ellos representados por mujeres.

\section{LA RELACIÓN DE ABU L-ḦASAN CON EL ELEMENTO FEMENINO: DEL ORIGEN MATERNO A LA PRÁCTICA MATRIMONIAL}

La figura de la mujer está muy presente en los orígenes familiares de los Banū Marīn y del propio Abū l-Ḥasan, aspecto que corresponde a la segunda línea temática ya resaltada del Musnad. Éstos son explicitados por Ibn Marzūq con el principal objeto de relacionar la adscripción beréber de esta dinastía a las tribus árabes, fenómeno sin el cual resultaba imposible entroncar su linaje con el entorno social del Mahoma o con el Profeta mismo. De hecho, y como era de esperar, admiraba tanto Abū 1-Ḥasan a aquellas personas que fuesen descendientes del Enviado de Dios o a los jerifes que "se les dio, en cada ciudad, lo que le era suficiente [para

\footnotetext{
${ }^{26}$ IBN MARZŪQ, Muhammad, Musnad, 193-194; trad. VIGUERA, 164.

${ }^{27}$ IBN MARZŪQ, Muhammad, Musnad, 194; trad. VIGUERA, 164-165.

${ }^{28}$ VIGUERA MOLINS, Mª Jesús, “"Vida ejemplar' de Abū 1-Ḥasan”, 51.

${ }^{29}$ VIGUERA MOLINS, Ma Jesús, "La compasión, virtud del sultán”, 178.
} 
vivir], fuera varón o hembra ( dakar $^{a n}$ awunțà) (...) para que no tuviera que salir a ganarse la vida, sino [sólo] trabajar para mejorar su condición" ${ }^{\prime 30}$.

En el caso de la dinastía meriní, ésta se hallaba "bastante más necesitada de legitimidad que sus coetáneas en al-Andalus y el Norte de África", limitación de la que fueron muy conscientes sus cronistas cortesanos ${ }^{31}$. El haber sustituido a los Almohades en sus territorios por la fuerza militar hacía imprescindible revestir a este nuevo linaje de su correspondiente halo de legitimidad ${ }^{32}$; y es que "tras los almohades (...) no traían estos benimerines, en su bagaje político, ninguna revolución espiritual, ni programa religioso original, que no usaron, pues, como razón para proclamarse y auto-legitimarse ni como justificación de sus ofensivas guerreras. Para suplir esta notoria carencia fundacional, (...) recurrieron a mostrarse como firmes defensores de la ortodoxia, uniendo también (...) actuación política y propaganda religiosa a través de un perfil ético ejemplar" ${ }^{33}$; y también un origen étnico referencial.

Al referir el origen beréber Zanāta de esta dinastía $a^{34}$ así como su cadena genealógica, Ibn Marzūq ya refleja la presencia femenina en ambos, pues relata cómo el hijo del ancestro de los Meriníes, Barr b. Qays b. 'Aylān, llegó persiguiendo a su camello hasta la tierra de sus parientes maternos, el país de los beréberes, donde contrajo matrimonio y tuvo un hijo, del que, según su teoría, desciende el pueblo amazigh. A continuación, menciona Ibn Marzūq a la hermana de este personaje, una mujer llamada Tumāḍiris ("Brillantez" en dicha lengua) que, a la muerte de Barr, compuso dos sentidas elegías, reproducidas ambas por este autor ${ }^{36}$.

Enlaza Ibn Marzūq, poco después, con la historia de la propia dinastía meriní, mencionando brevemente los reinados de sus primeros emires, desde Muhammad,

${ }^{30}$ IBN MARZŪQ, Muhammad, Musnad, 148; trad. VIGUERA, 129.

${ }^{31}$ MANZANO RODRÍGUEZ, Miguel Ángel, "Biografías y poder político", 257.

${ }^{32}$ MANZANO RODRÍGUEZ, Miguel Ángel, "Biografías y poder político", 257; MANZANO RODRÍGUEZ, Miguel Ángel, "Onomástica benimerín: el problema de la legitimidad", en Estudios Onomástico-Biográficos de Al-Andalus, M. L. Ávila (ed.),(1989), 120.

${ }^{33}$ VIGUERA MOLINS, Ma Jesús, "La compasión, virtud del sultán", 191; VIGUERA MOLINS, $\mathrm{M}^{\mathrm{a}}$ Jesús, “Vida ejemplar' de Abū l-Ḥasan”, 54.

${ }^{34}$ KHANEBOUBI, Ahmed, Les premiers sultans merinides (1269-1331). Histoire politique et sociale, París, 1987,33-34.

${ }^{35}$ Esta información es reproducida, igualmente, por IBN ABŪ ZAR' AL-FĀSŪ, 'Alī, Al-Anīs almutrib bi-Raẉ̣ al-qirțās fì ajbār mulūk al-Magrib wa-ta'rīj madīnat Fās. Ed. 'Abd al-Wahhāb b. Manșūr, Rabat, 1999², 366-367, de manera más amplia, cronista que Ibn Marzūq reconoce explícitamente en el Musnad haber consultado para estos datos. Véase SHATZMILLER, Maya, L'Historiographie mérinide. Ibn Khaldūn et ses contemporains, Leiden, 1982, 115-123 y, de la misma autora, "Le mythe de origine berbère. Aspects historiographiques et sociaux", Revue de l'Occident Musulman et de la Mediterranée, 35 (1983), 145-156; MANZANO RODRÍGUEZ, Miguel Ángel, La intervención de los Benimerines en la península Ibérica, Madrid, 1992, XXV; DE FELIPE, Helena, "Leyendas árabes sobre el origen de los beréberes", Al-Qanțara, 11(1990), 379-396, esp. 386-487; FIERRO, Maribel, "Las genealogías de 'Abd al-Mu'min, primer califa almohade", Al-Qanțara, 24/1(2003), 77-107, esp. 87.

${ }^{36}$ IBN MARZŪQ, Muhammad, Musnad, 108; trad. VIGUERA, 96. 
pasando por los de Abū Bakr b. Ḥamāma y Maḥyū hasta el de Abū Muḥammad 'Abd al-Ḥaqq, al que sucedió su hijo Abū Sa'īd 'Utimān (614-638/1217-1240). Es en el espacio que dedica a éste último donde Ibn Marzūq subraya la presencia de la mujer en dicha genealogía, pues menciona a su madre, al-Nuwwār bint Ḥafṣ alWanŷāsiniyya $^{37}$, cuyo nombre árabe significaba "flor, especialmente blanca". Una vez asesinado dicho emir en pleno día, narra este cronista cómo fue sustituido por su hermano Abū Ma'rūf Muhammad (638-642/1240-1244), quien era de madre diferente, una mujer beréber de la tribu de Gumāra (ummu-hu gumariyya $)^{38}$. Al-Nuwwār engendraría, según sus palabras, también al siguiente emir de la dinastía, Abū Bakr, descrito por el autor como "hermano ( $\check{s} a q \bar{\imath} q)$ de doble vínculo de Muḥammad"

Sin embargo, la fémina que mayor atención acapara y que más elogios recibe por parte de Ibn Marzūq es, sin duda, la madre (wālida) del sultán meriní protagonista de su crónica, Abū 1-Ḥasan. Aunque el autor del Musnad no revela en ningún momento el nombre de esta reverenciada mujer, por una simple actitud de respeto hacia la inviolabilidad de su persona, sí sabemos por otros cronistas que se llamaba al- $\operatorname{Anbar}^{40}$ ("El Ámbar"), nombre de gran carga metafórica que designaba tanto una sustancia altamente valorada en el Oriente islámico como un perfume de agradable aroma $^{41}$. Ibn Marzūq obvia también mencionar la procedencia geográfica y social de esta mujer de quien sí sabemos, a tenor de otras fuentes, que era una esclava abisinia (habašiyya). Así la define, por ejemplo, Ibn Jaldūn (m. 808/1406) ${ }^{42}$ al referir al sultán Abū 1-Ḥasan quien, debido al origen africano de su madre, debía de ser negro, hecho que tampoco dudan en reflejar las fuentes castellanas ${ }^{43}$, como la Gran Crónica de Alfonso $X I^{44}$, donde se afirma que el mencionado sultán "era negro e hijo d'Anbar la negra". Advertimos que el origen abisinio y concubino de 'Anbar parece legitimado por Ibn Marzūq con la previa mención en su obra de la ya mencionada Umm Ayman o Baraka bint Ta'alaba b. 'Amr, cuidadora de Mahoma, mujer curio-

${ }^{37}$ IBN MARZŪQ, Muhammad, Musnad, 112; trad. VIGUERA, 99.

${ }^{38}$ IBN MARZŪQ, Muhammad, Musnad, 112; trad. VIGUERA, 99.

${ }^{39}$ IBN MARZŪQ, Muḥammad, Musnad, 112; trad. VIGUERA, 99.

${ }^{40}$ Mencionada por IBN AL-AḤMAR, Abū l-Walīd, Rawdat al-nisrīn fì dawlat Ban̄̄ Marīn, Ed. 'Abd al-Wahhāb Ibn Manșūr, Rabat, 1991, 35; IBN AL-AḤMAR, Abū 1-Walīd, Al-Nafḥa alnisrīniyya wa-l-lamha al-marīniyya, Ed. Dr. 'Adnān Muḥammad Āl Ṭu ma, Damasco, 1992, 47.

${ }^{41}$ RUSKA, J.; PLESNER, M., “'Anbar”, en Encyclopaedia of Islam, H. A. R. Gibb, J. H. Kramers, E. Lévi-Provençal y J. Schacht (eds.), Leiden, 1979, vol. I, 484; RĀĠIB, Yūsuf, "Esclaves et affranchistrahis par leur nom dans les arts de l'Islam medieval", en Le non-dits du nom. Onomastique et Documents en terres d'Islam, C. Müller y M- Roiland-Rouabah (dirs.), (2013), 1.

${ }^{42}$ IBN JALDŪN, 'Abd al-Rahmān, Kitāb al- 'ibar, Beirut, 1992, vol. VII, 288; y ed. Būlāq, VII, 267.

${ }^{43}$ MANZANO RODRÍGUEZ, Miguel Ángel, "Biografías y poder político", 254 y nota al pie 25; AL-HARŪRŪ, Muhammad 'Ūsà, Ta'rīj al-Magrib al-Islāmī wa-l-Andalus fì 'aṣr al-marīn̄i, Kuwait, $1987^{2}, 109$.

${ }^{44}$ Ed. D. CATALÁN. Madrid: 1977, vol. II, cap. CCXXXV, 231, apud MANZANO RODRÍGUEZ, Miguel Ángel, "Biografías y poder político”, 254 y nota al pie 25. 
samente de la misma procedencia y origen social que la progenitora de Abū 1-Ḥasan, que, ante esta identificación, parece quedar encumbrada a la cima de la santidad.

Aunque al-'Anbar no era beréber ni musulmana en su origen, ello no restó mérito a la importancia por ella alcanzada. Así se desprende de todos los elogios que le rinde el autor del Musnad en distintos puntos de éste. Sabemos que esta mujer, que el historiador nazarí Ibn al-Aḥmar (m. 807/1404) describe como piadosa (al-ṣăliḥa), ilustre (al-fādila) y bendecida (al-mubāraka $)^{45}$, engendró a numerosos sultanes, llegando a ejercer una gran influencia tanto en las decisiones políticas como en la bondad de Abū 1-Ḥasan, que es descrita por nuestro autor en un párrafo entero plagado de cuidadosas palabras ${ }^{46}$ :

Era delicada, clemente y llena de tal compasión para con los demás que causaba asombro. ¡A cuántos huérfanos dotó y cuántos matrimonios propició! ¡Cuántas limosnas y cuántos dones repartió! También [deben mencionarse] sus continuos ayunos y los presentes [que enviaba] para las sagradas ceremonias de inmolación de La Meca. Después de haber decidido peregrinar a La Ka 'ba, se lo impidió la muerte. Era la más misericordiosa criatura de Dios para con todos los seres. Me contó un día su insigne hijo, el mawlà [Abū 1-Ḥasan]: «Entré un día a verla y me habló sobre los de Tremecén, para que les levantara el asedio. Como me insistiera mucho, quise contrariarla y le dije que los de allí la insultaban, pretendiendo con eso que dejara de hablarme de aquel asunto. Pero me respondió: "Hijo mío, esto es lo que me mueve a mencionártelos, pues así mis palabras en su favor serán puras ante la faz de Dios, en busca de Su sola recompensa". Yo le contesté que la Ley me obligaba a hacerlo y le expliqué aquello desde el punto de vista legal. Y entonces cedió.

Que el emir Abū l-Hasan sentía una gran veneración por su madre es un hecho que se desprende del capítulo más ilustrativo de toda la obra a este respecto, el diecisiete. Este apartado, titulado "De su devoción filial" (fi birri-hi bi-abaway-hi) $)^{47}$, llama la atención de principio a fin, pues curiosamente concede, sin ningún reparo, mucha mayor importancia al respeto que este soberano rendía hacia su progenitora que la que demostraba hacia su padre, tema que sólo ocupa aproximadamente un cuarto del capítulo. Ibn Marzūq no olvida mencionar igualmente a la abuela paterna de Abū l-Ḥasan, quien era hermana del šayj y peregrino (hââŷy Abū Zayyān Sultạn b. Muhalhil ${ }^{48}$, aunque no revela su nombre, laguna que puede cubrirse gracias a Ibn $A b i ̄ Z^{\prime}{ }^{4}{ }^{49}$, por quien sabemos que se llamaba ' $\bar{A}$ 'iša y que era hija de Abū 'Ațiyya Muhalhil b. Yahyà al-Julțī.

Esta sección sobre la veneración materna del emir comienza con unas máximas de la Tradición islámica que exhortan a rendir respeto hacia los progenitores e ilus-

${ }^{45}$ IBN AL-AHMAR, Abūl-Walīd Ismā'īl, Rawḍat al-nișrīn, 35; IBN AL-AHMAR, Abū l-Walīd Ismā̄̄il, Al-Nafha al-nisrīniyya, 47.

${ }^{46}$ IBN MARZŪQ, Muhammad, Musnad, 122-123; trad. VIGUERA, 107.

${ }^{47}$ IBN MARZŪQ, Muhammad, Musnad, 237 y ss.; trad. VIGUERA, 197.

${ }^{48}$ IBN MARZŪQ, Muḥammad, Musnad, 371; trad. VIGUERA, 307.

${ }^{49} \mathrm{IBN}$ ABŪ ZAR' AL-FĀS̄̄, 'Alī, Al-Anīs al-mutrib, 522. 
tran la virtud de la devoción filial, entre las que se da cita un hadiz especialmente hermoso, tomado de Abū Hurayra (m. 59/681): "Vino junto al Enviado de Dios un hombre y le dijo: «Enviado de Dios, ¿qué persona merece más mi amistad?», y respondió: «Tu madre». Y volvió a preguntar: «Y luego ¿quién?». Y respondió: «Tu madre $»^{50}$. Ibn Marzūq ofrece otro ejemplo que insiste en este comportamiento, según el cual en cierta ocasión Mahoma ordenó a un hombre, que había acusado a su propio padre de hurtarle dinero, "ser bueno con su madre" con gran tesón, "por las penas del embarazo, parto y crianza" ". A este caso añade el autor a continuación el siguiente, tomado del cadí Abū Bakr b. al-'Arabī: "Oí en Bagdad al šayj de los Hambalíes , Abū l-Wafā' b. 'Aqīl, que decía: «El hijo sigue a su madre en la esclavitud y en la libertad, porque está apartado de su padre, cuya semilla no le confiere ningún mérito ni categoría, pues él se forma en las entrañas, dentro de ella, convirtiéndose así para él en un santuario. Es igual que un hombre que come dátiles en un campo y cae de su mano un hueso, del cual nace una palmera, ¿tiene acaso este hombre algún derecho sobre esa palmera?, ¿no lo tiene por entero el dueño del campo?». Magnífica parábola"šs. Evidencia, asimismo, Ibn Marzūq cómo Abū 1Hasan era consciente del amor debido a la figura materna pues, según relata, "todos los días solía decir [el emir]: «Cuatro gozarán del Paraíso, por lo que dice el Altísimo de que el Paraíso se encuentra a los pies de las madres» $"{ }^{{ }_{53}}$.

La segunda sección de este capítulo es la más extensa y explícita a este respecto, pues abre una gran ventana hacia la relación de Abū 1-Ḥasan con su progenitora. Comienza esta delicada parte diciendo: "No han visto sus contemporáneos devoción mayor para con una madre que la suya". Y es que este emir, según el testimonio cercano de Ibn Marzūq y de otros personajes también asiduos a él, "jamás salía por las mañanas sin besar sus pies ni jamás se retiró por las noches sin hacer lo mismo". La influencia de esta mujer tanto en las decisiones políticas de este emir, según ya pudo advertirse en una anécdota reproducida previamente, como en su integridad moral era bastante considerable; así se desprende de la siguiente afirmación de Ibn Marzūq ${ }^{54}$ : "Repetidas veces le oí contar que ella intercedía ante él [Abū 1-Ḥasan] por el perdón de su persona, y él comentaba: «No podía rechazar [su recomendación] y me era difícil acceder a ella. Entonces ella me decía: "Alī, quizás te haya seducido tu poder, apartándote de mis derechos". Encontraba en estas palabras el aviso de Dios, y corría a besarle los pies y a darle satisfacción; durante varios días me seguía sintiendo muy avergonzado ante ella y temía que cambiara su concepto de mí»»". Así sucedió en múltiples ocasiones, siendo una de ellas el asedio de la ciudad de Tremecén por parte de Abū l-Ḥasan, acaecido en el año 737 (1337), durante el cual

\footnotetext{
${ }^{50}$ IBN MARZŪQ, Muhammad, Musnad, 237; trad. VIGUERA, 197.

${ }^{51}$ IBN MARZŪQ, Muhammad, Musnad, 238-239; trad. VIGUERA, 198.

${ }^{52}$ IBN MARZŪQ, Muhammad, Musnad, 239; trad. VIGUERA, 198.

${ }^{53}$ IBN MARZŪQ, Muhammad, Musnad, 240; trad. VIGUERA, 200.

${ }^{54}$ IBN MARZŪQ, Muḥammad, Musnad, 240; trad. VIGUERA, 199.
} 
reconocía el emir meriní no haber tenido necesidad de encomendarse a Dios "pues ella le imploraba por mí"ss. El respeto que el emir profesaba a su progenitora se reflejaba, igualmente, en el trato tan favorable que él dispensaba a los hombres y las mujeres (min rîya $\bar{a} l$ wa-l-nis $\bar{a}$ ) que la atendían ${ }^{56}$, siendo éste un dato bastante curioso, pues revela que personas de sexo masculino también se ocupaban del cuidado diario de esta sultana madre.

Quizás el hecho de la vida de al- 'Anbar que más llama la atención, sobre todo por su origen no musulmán, es su gran empeño por realizar la peregrinación a La Meca. Relata Ibn Marzūq cómo planeó esta mujer cumplir con el deber de visitar los Santos Lugares del Islam, deseos que el emir Abū 1-Ḥasan no dudó en cumplir a pesar de estar ocupado con el asedio de Tremecén, prometiéndoselo a su madre una vez hubiese concluido éste. Tal viaje se produjo, pues, en el año 737 (1336-1337), en que también partió hacia La Meca un tal 'Uțmān b. Ŷarrār, quien le informó en persona a Ibn Marzūq en el propio Hị̂̄āz de que la madre de Abū 1-Ḥasan había llegado bien a su sagrado destino. De ello dio debida cuenta un secretario magrebí que redactó en El Cairo un escrito anunciando la llegada de al-'Anbar a La Meca, con las disposiciones necesarias de su visita. En dicho comunicado, se instaba a dispensar un trato especial a la madre de Abū 1-Ḥasan, privilegio que ella misma rechazó dando ejemplo de su gran humildad ${ }^{57}$, aunque el sultán de Egipto daba cumplidas muestras de respeto hacia ella.

Lamentablemente, la madre de Abū 1-Ḥasan fallecería durante el transcurso de visita a los Lugares Santos. Narra Ibn Marzūq que, estando él con el mencionado emir en Tremecén, les llegó la noticia del fallecimiento de al- Anbar. Era el día 18 de ramadán del año 737 (30 de abril de 1337), días antes, por lo tanto, de la conquista de Tremecén, acaecida el 27 de dicho mes $^{58}$. Desde esta ciudad fue trasladada al cementerio real meriní de Chella, donde recibió inhumación ${ }^{59}$. Según relata el autor del Musnad, el día en que ella falleció, Abū 1-Ḥasan se puso las armaduras debajo de su vestimenta, "siendo éste el colmo de la fe y de la confianza en Dios, y de cumplir sus deberes filiales para con su madre" ${ }^{00}$. A su funeral convocó el sultán a todos los jerifes, ulemas y santos para que la acompañaran en su cortejo fúnebre hasta Chella, ordenando Abū 1-Ḥasan incluso erigir "una mezquita, una casa y un oratorio en cada etapa que [la comitiva fúnebre] cumplió desde Tremecén hasta Chella"; una medida, como apunta el autor, con la que "se volvieron seguros los

${ }^{55}$ IBN MARZŪQ, Muhammad, Musnad, 240; trad. VIGUERA, 200.

${ }^{56}$ IBN MARZŪQ, Muḥammad, Musnad, 242; trad. VIGUERA, 201.

${ }^{57}$ IBN MARZŪQ, Muhammad, Musnad, 241; trad. VIGUERA, 200.

${ }^{58}$ IBN MARZŪQ, Muhammad, Musnad, 241; trad. VIGUERA, 200-201.

${ }^{59}$ IBN MARZŪQ, Muḥammad, Musnad, 108. Sobre este cementerio, véase el referencial artículo de BASSET, Henri y LÉVI-PROVENÇAL, E., "Chella, une necropole mérinide", Hesperis, 2 (1922), 1-92, 255-316 y 385-425, en el que, curiosamente, no se menciona a al- 'Anbar entre los miembros femeninos de la dinastía meriní enterrados en esta necrópolis.

${ }^{60}$ IBN MARZŪQ, Muhammad, Musnad, 240; trad. VIGUERA, 200. 
caminos y aumentaron las comodidades", de modo que la gente tuvo en ello pruebas de la bendición (baraka) de esta mujer, tanto en vida de ella como una vez fallecida. "Instituyó también [el emir] por ella como habices muchos inmuebles cuyos beneficios siguen todavía" ${ }^{1}$.

Narra también Ibn Marzūq que, tras el óbito de al-'Anbar, "reunió [su hijo Abū 1-Hasan] sus ropas y muebles, y todos los enseres y mobiliario que ella poseía, además de otras cosas, y las dio como limosna, sin regalar nada de ello a ninguna persona por [interés] mundano", ordenando el emir al tío paterno de Ibn Marzūq dar determinada cantidad de ropa y muebles "como limosna a las mujeres santas y virtuosas que viven cerca del mausoleo de mi señor Abū Madyan y a las viudas que para sus maridos fueron buenas esposas" ${ }^{2}$. Y es que "su devoción filial para con ella está muy por encima de lo que yo he logrado describir en resumen", según concluye en este apartado Ibn Marzū $q^{63}$.

Consta que, a la muerte de al-'Anbar, el padre del emir Abū 1-Ḥasan, el sultán Abū Sa'īd 'Uțmān (710-732/1310-1331), tomó una concubina, de nombre Maryam ${ }^{64}$, mujer que también acapara cierta atención en esta obra. Era ésta una esclava liberta, favorita de su padre (haziyyat wälidi-hi), pues recibe el epíteto de al-hurra en el texto del Musnad, fuente por la que también sabemos que tenía muy buena relación con el protagonista ya que, en palabras de Ibn Marzūq, "había criado a nuestro señor [Abū l-Ḥasan] y le guardaba cariño", siendo como una segunda madre para este sultán ${ }^{65}$. Con ella tuvo Abū Sa ${ }^{6} \overline{1} d$ Utimān una niña, hermana, pues de Abū 1-Ḥasan, cuyo nombre no se revela, y que pudo ser desposada con "el noble y excelente $\check{s}$ ayj Abū Ḥassūn Zayyān b. Ḥassūn b. Āmadyūn, quien era cuñado (șiḥr) del sultán", según revela también el Musnad ${ }^{66}$.

Volviendo a la mención de Maryam, consta que su hijastro, Abū 1-Hasan, la ayudó a realizar la peregrinación, al igual que había hecho con su propia madre, formulando la petición por escrito en respuesta al señor de Egipto. El emir meriní se encargó, igualmente, de gestionar los bienes que su madrastra debía llevar en su viaje y con los que él "procuraba facilitar el curso de la Peregrinación"; unos presentes que consistieron en 3.700 dinares de oro, alquiceles y mulos, como desvela Ibn Marzūq más tarde ${ }^{67}$. Como broche de oro, el emir meriní realizó una copia del Corán de su puño y letra, según era su afición, para que fuese llevada por la concubina de su padre (umm walad abi-hi) y su comitiva a la ciudad de Medina, donde

${ }^{61}$ IBN MARZŪQ, Muhammad, Musnad, 242-243; trad. VIGUERA, 201-202.

${ }^{62}$ IBN MARZŪQ, Muḥammad, 242; trad. VIGUERA, Musnad, 201.

${ }^{63}$ IBN MARZŪQ, Muhammad, Musnad, 234; trad. VIGUERA, 202.

${ }^{64}$ Según VIGUERA MOLÍNS, Ma Jesús, Musnad, 569, esta mujer es también mencionada por ALMAQQARĪ, Nafḥ al-țīb min guṣn al-Andalus al-ratīb wa-dikr wazìri-hā Lisān al-Dīn Ibn al-Jațīb, Ed. Iḥsān 'Abbās, Beirut, 1968, vol. IV, 402, quien toma la información directamente del Musnad.

${ }^{65}$ IBN MARZŪQ, Muhammad, Musnad, 242, 392-393, 453 y 454; trad. VIGUERA, 201, 392 y 374.

${ }^{66}$ IBN MARZŪQ, Muḥammad, Musnad, 242 y 254; trad. VIGUERA, 201 y 305.

${ }^{67}$ IBN MARZŪQ, Muḥammad, Musnad, 242, 453, 475; trad. VIGUERA, 201, 374 y 392. 
finalmente quedó depositada. Dicho volumen fue terminado de copiar un viernes del mes de $r a b \imath^{`}$ I del año 740 (septiembre de 1339), antes de la oración comunitaria, fecha que nos permite fijar el radio cronológico en el que la sultana Maryam debió de viajar a Oriente ${ }^{68}$. No se olvidó, por último, Abū 1-Ḥasan de "las mujeres (al-niswa) que iban a viajar acompañando a la horra" Maryam, a quienes también dispensó 770 dinares de oro ${ }^{69}$.

Nada más revela Ibn Marzūq acerca de la segunda esposa de su padre; tan sólo podemos deducir, por una referencia posterior, que tal vez pudo ser ella la mujer a la que le encomendó velar por las pertenencias del emir $\mathrm{Abu} \mathrm{Sa}{ }^{\prime} \bar{i} d$ a su muerte. Y es que revela Ibn Marzūq cómo, una vez fallecido éste, Abū 1-Ḥasan "encargó a una de sus favoritas (min hazāay $\bar{a}-h i$ ) que conservara en el mismo estado el lecho que [su padre] tenía en su almacería (al-mașriyya), situada sobre la Puerta de Bastana, dentro de la Puerta de al-Zaŷŷārī [Tremecén la Nueva], junto con el armario de sus libros, todo, tal y como habían estado; y él [Abū l-Ḥasan] entraba allí para rezar, con respeto, evitando sentarse sobre [el lecho] por deferencia" ${ }^{\circ}$. Porque "cuando muere un hombre se terminan todas sus acciones, menos tres: la limosna que practicó, la ciencia que cultivó y un buen hijo que reza por él", según recuerda la Tradición islámica ${ }^{71}$.

Si la relación de Abū 1-Ḥasan con su madre y con su madrastra según el Musnad merece ser destacada, también lo es la que este sultán tuvo con sus mujeres. Comienza Ibn Marzūq desvelando que el emir meriní solía preferir a aquélla que su madre, la referida al- Anbar, le señalaba, pues en todo cumplía sus deseos ${ }^{72}$. Aunque de manera muy somera, el capítulo tercero de la mencionada obra resalta la virilidad sana y completa (dalīl al-kamāl wa-șihha al-dukuriyya) que caracterizaba a este soberano, cualidad que, en opinión de Ibn Marzūq, debía constituir un motivo de orgullo, pues la recomiendan tanto el Corán como la Sunna. Refiere dicho cronista la gran inclinación hacia el matrimonio (nikāhn) que sentía el emir Abū 1-Hasan, al igual que hiciera el propio profeta Mahoma, según transmiten múltiples hadices que son reproducidos. Sin embargo, Ibn Marzūq contrapone esta inclinación a la opinión mantenida por algunos ulemas acerca de la no conveniencia de frecuentar a las mujeres por considerar que tal práctica iba en contra de la vida ascética, en la que también destacó con creces este soberano ${ }^{73}$.

No obstante, llama la atención el sublime respeto que, a tenor de esta fuente, profesaba el emir Abū 1-Ḥasan por la figura femenina, una mesura que transmitió a

${ }^{68}$ IBN MARZŪQ, Muhammad, Musnad, 475; trad. VIGUERA, 392-393.

${ }^{69}$ IBN MARZŪQ, Muḥammad, Musnad, 454; trad. VIGUERA, 374.

${ }^{70}$ IBN MARZŪQ, Muḥammad, Musnad, 247-248; trad. VIGUERA, 205.

${ }^{71}$ Hadiz transmitido por Muslim que cita IBN MARZŪQ, Muḥammad, Musnad, 258; trad. VIGUERA, 213.

${ }^{72}$ IBN MARZŪQ, Muhammad, Musnad, 240; trad. VIGUERA, 200.

${ }^{73}$ IBN MARZŪQ, Muḥammad, Musnad, 131-132; trad. VIGUERA, 115-116. 
sus propios descendientes y que él mismo tomó de ejemplos de la Tradición islámica. En este sentido Ibn Marzūq resalta el pudor que caracterizaba a este sultán, haciendo uso de una tradición, transmitida por Abū Sa īid al-Judrī (m. 74/693), de tinte femenino que reproduce en el capítulo dieciséis y que revela cómo "era el Enviado de Dios más pudoroso que las vírgenes en la intimidad" ". Igualmente, Ibn Marzūq, reproduce un consejo que Hiārit $b$. Ka 'b dio a su hijo sobre este y otros temas, cuya versión abreviada ofrecemos a continuación: "Hijo mío, ya tengo ciento sesenta años y jamás estreché la mano de ningún malvado, ni he abrazado a ningún traidor, ni en cosas pequeñas he sido avaro con ningún amigo, ni nunca una mala mujer puso su manto en mi casa, ni miré con concupiscencia a ninguna prima ni a ninguna cuñada ni a ninguna nuera (...). Hijos míos (...), casad a las mujeres con quien les convenga y que el agua sea su mejor perfume (...)" 75 .

Abū l-Ḥasan hizo gala de su respetuoso comportamiento hacia las mujeres en multitud de ocasiones, como puede advertirse a lo largo del Musnad y, de manera especial, en un caso que esta fuente recoge y en el que se hizo manifiesto su puritanismo: "El primer día que le leía yo el Ŷămi de al-Bujārī estaban presentes sus hijos, el santo y piadoso emir Abū l-Nāṣir, el emir Abū l-Fạ̣l y el sultán Abū 'Inān, y al leer el primer hadiz mencioné su complemento, que es el dicho [del Profeta]: "Aquel que parte en busca de unas riquezas que obtener o de una mujer ( $i m r \vec{a}$ 'a) con la que casarse, emigra por lo que emigra», se pusieron sus hijos de pie, pues estaban acostumbrados a que no se mencionara a la mujer (al-mar'a) delante de ellos, en presencia de su padre, y así, cuando alguien formulaba una denuncia en la que se mencionaba una mujer, se apartaban y salían del Consejo" "76.

La hombría y la religiosidad de Abū l-Ḥasan constituyen un binomio también resaltado en una anécdota recogida en el capítulo cuarto de esta obra, en el que Ibn Marzūq reproduce una confidencia que, en cierta ocasión, le hizo el propio emir. Según le relató este último, durante su juventud a veces le acaecían poluciones nocturnas y le avergonzaba ir al baño para lavarse, optando muchas noches por ir al río a asearse a pesar de poder perder la oración comunitaria y del frío que arreciaba. Como realizaba tal ritual de limpieza en un lugar de abluciones y purificaciones, cerca de la mezquita al-Nașșāṣ̄in (Tremecén), el mismo Abū l-Ḥasan ordenaría más tarde erigir y restaurar en dicho lugar otro templo ${ }^{77}$. No es esta la única mención a temas sexuales que hace, aunque de manera subliminal, el texto del Musnad; aunque no relacionada especialmente con la figura del sultán, esta fuente se remonta a una anécdota lejana, según la cual "un viejo decrépito que fue a ver a Mu'āwiyya [b. Abī Sufyān (41-60/661-680)] y éste le preguntó: «¿Cómo estás, anciano?», a lo que respondió: «¿Qué cosas me preguntas, Príncipe de los Creyentes? Se me ha agudi-

\footnotetext{
${ }^{74}$ IBN MARZŪQ, Muhammad, Musnad, 227; trad. VIGUERA, 190.

${ }^{75}$ IBN MARZŪQ, Muhammad, Musnad, 349.

${ }^{76}$ IBN MARZŪQ, Muḥammad, Musnad, 234-235; trad. VIGUERA, 196.

${ }^{77}$ IBN MARZŪQ, Muḥammad, Musnad, 134; trad. VIGUERA, 118.
} 
zado lo que me hubiera gustado que decreciera y ha disminuido lo que me hubiera gustado que aumentara: amé mucho a las mujeres (al-nișā) y ellas son [ahora] mis enfermeras $\left(a l-\check{s} a f f \bar{a}^{\prime}\right) »{ }^{\prime}{ }^{\prime}>$.

Pero ¿quiénes fueron las mujeres de la vida de Abū l-Hasan? Como era de esperar, Ibn Marzūq se muestra bastante cometido a la hora de mencionar, con nombre propio, a las esposas que tomó este sultán. La primera noticia al respecto que hallamos en el Musnad la ofrece su autor en el capítulo veinte de la obra. En él, revela que un personaje muy cercano al emir, llamado Abū Isḥāq Ibrāhīm b. Abī Yahyyà Abī Bakr al-Tasūlī al-Tāzī, a quien aquél confiaba a veces la realización de embajadas en su nombre por su gran amistad, acompañó en cierta ocasión a Abū 'Abd Allāh al-Satțīi, "enviado a Túnez con motivo del compromiso matrimonial [de Abu 1-Hasan]". Y es que dicho viaje tenía por fin pedir la mano de una princesa hạș̣í, hija del sultán tunecino Abū Yahyà Abū Bakr (718-747/1318-1346) ${ }^{79}$ y hermana, a su vez, de Abū l-'Abbās al-Faḍl. Aunque Ibn Marzūq no llega a revelar su nombre, sabemos por otras crónicas que la novia se llamaba Fāṭima ${ }^{80}$. Según alude Ibn Marzūq, cuando la prometida de Abū l-Ḥasan ya había salido de Túnez camino de Fez para sus esponsales, acompañada de los servidores de su padre y de los delegados de Abū l-Ḥasan (Abū Zayyān 'Arīf b. Yahyà y los alfaquíes Abū 'Abd Allāh alSațtị y Abū l-Fạ̣l b. Abī Madyan), aquél murió, enterándose ella de su fallecimiento una vez arribada a tierras meriníes en el año 731 (1330-1331)

Pero, si hay una información original y relevante relativa a dicho traslado, esa es sin duda la que Ibn Marzūq ofrece más adelante, al llegar al capítulo cincuenta de su Musnad, dedicado a ensalzar la magnificencia y la grandeza de miras del emir Abū 1-Ḥasan. En esta sección, relata Ibn Marzūq en primera persona un hecho del que él fue testigo presencial. Este fragmento narra los preparativos que dicho sultán dispuso para recibir a la princesa hafșí que iba a desposar, para la que preparó los mejores aposentos nunca vistos, pues bien es sabido que este soberano meriní "construyó nobles y bellos edificios, bajo los dictados de su celo eximio", en palabras del cronista nazarí Ibn al-Jațīb (m. 776/1374) $)^{82}$. Dice el texto lo siguiente:

Al aproximarse a Tremecén anunciaron, desde al-Bațạā' [fortaleza cercana a Argel], su llegada [de la princesa meriní]. Entonces él [Abū l-Hasan] y yo [Ibn Marzūq] recorrimos la ciudad para encontrarle una casa apropiada. Cuando dábamos vueltas por las casas, [el emir] me dijo: «Por Dios, no mostraría mucha consideración ni deferencia hacia esta [señora] que llega, si la albergáramos en una casa en la que han vivido otras

${ }^{78}$ IBN MARZŪQ, Muhammad, Musnad, 425; trad. VIGUERA, 349-350.

${ }^{79}$ KHANEBOUBI, Ahmed. Les premiers sultans merinides, 66; BRUNSCHVIG, Robert, La Berbérie Orientale sous les Hafșides.Des origines a la fin du XV siècle, París, 1940, 149.

${ }^{80}$ VIGUERA MOLÍNS, Ma Jesús, "La exaltación biográfica de Abū 1-Ḥasan”, 411, notal al pie 22; AL-HARŪRŪ, Muhammad 'Ūsà, Ta'rīj al-Magrib, 116-117.

${ }^{81}$ IBN MARZŪQ, Muhammad, Musnad, 448; trad. VIGUERA, 294-295.

${ }^{82}$ VIGUERA MOLÍNS, Ma Jesús, "La exaltación biográfica de Abū 1-Ḥasan”, 421. 
personas; convendría construirle una residencia especial». Repuse: «Sí, si tuviéramos tiempo para hacerlo». Y exclamó [Abū 1-Ḥasan]: «Pero, ¿dónde se vería entonces la solicitud que le tengo y el poder con el que Dios me ha distinguido?; traedme a todos los maestros de obras de albañilería, carpintería, yesería, azulejos, mármoles, fontanería, pintores, forjadores y fundidores». Se trajeron a su presencia y él les dijo: «Quiero una casa de cuatro habitaciones, todas diferentes, y dos pabellones contiguos, con los muros adornados con motivos diversos, en yeso y azulejos. Las tallas en madera de alerce endurecido, con motivos florales y poligonales. El patio de la casa estará decorado, revestido de azulejos y mármoles con losas de mármol y columnas. La obra de carpintería de los techos será diferente en cada habitación, con motivos florales y poligonales pintados, según los procedimientos artísticos usuales. Las puertas serán de marquetería de madera, como también todas las alhacenas y portillos. Todos los ornamentos serán de cobre bañado en oro y de hierro recubierto de estaño». Les dibujó sobre un papel el plan de conjunto y lo acordó con todos ellos. Una vez que les explicó con detalle lo que debían hacer, les dijo: «Quiero que esté hecha tal día, dentro de una semana, y entonces, si Dios quiere, vendré a visitarla». Respondieron: «Imploramos la ayuda de Dios y la tuya». Cuando se cumplió el plazo y llegó el día señalado, se dirigió a aquel lugar (y yo [Ibn Marzūq] le acompañé) para comprobar si todo estaba hecho conforme a sus explicaciones y a sus indicaciones. Resultó una muestra ejemplar de su magnificencia y poderío, y prueba de todo lo demás ${ }^{83}$.

La célebre batalla del Salado (741/1340), tan desastrosa para los Meriníes, pondría fin a la vida de esta princesa hafșín ${ }^{84}$, tras lo cual Abū l-Ḥasan contrajo nuevas nupcias con su hermana, hija también de dicho emir hafșí, llamada 'Azzūna ${ }^{85}$. Todas estas noticias, recién expuestas, encierran un gran valor, pues evidencian que el emir Abū 1-Ḥasan emparentó, efectivamente, con la dinastía tunecina, con la que los meriníes no solamente establecieron relaciones diplomáticas sino también familiares, obviamente con meros fines políticos.

Por último, Ibn Marzūq menciona, aunque de pasada, a otra de las esposas que tomara el emir Abū 1-Ḥasan, la madre del emir Abū 'Inān (749-759/1348-1358), cuyo nombre se reserva, limitándose tan sólo a situarla en la ciudad argelina de Constantina, a la que fue enviado Ibn Marzūq con la delicada misión de sacar a algunos familiares del emir Abū 1-Ḥasan de dicha ciudad. Del relato se desprende que dicha mujer falleció, finalmente, cerca de Tremecén ${ }^{86}$.

${ }^{83}$ IBN MARZŪQ, Muhammad, Musnad, 448-449; trad. VIGUERA, 370.

${ }^{84}$ IBN JALDŪN, Kitāb al- íbar, VII, 347, Berbères, IV, p. 233; Crónica de Alfonso XI, Cap. CCLI, 327, apud MANZANO RODRÍGUEZ, Miguel Ángel, La intervención de los Benimerines en la península Ibérica, Madrid, 1992, 264, nota al pie 754.

${ }^{85}$ VIGUERA MOLINS, Ma Jesús, "La exaltación biográfica de Abū 1-Ḥasan”, 411, notal al pie 22; AL-HARŪRŪ, Muhammad 'Ūsà, Ta'rīj al-Magrib, 116-117.

${ }^{86}$ IBN MARZŪQ, Muḥammad, Musnad, 497; trad. VIGUERA, 412. 


\section{OTRAS REFERENCIAS FEMENINAS EN EL MUSNAD}

El texto del Musnad se halla, finalmente, salpicado de referencias que, aunque inconexas entre sí, ofrecen en su conjunto informaciones bastante curiosas acerca de la realidad social de la mujeres en el siglo XIV, englobando tanto a féminas de distintos territorios islámicos -el meriní, el andalusí o el zayyāní-, como de otras comunidades religiosas-tales como la judía o la cristiana, incluyendo incluso a las de la realeza castellana-. Otras noticias recogen información acerca de otros temas femeninos bastante diversos, desde la existencia de esclavas reales y las funciones desempeñadas por éstas, hasta menciones a la propia madre del autor de la obra, Ibn Marzūq. Estos datos dispersos constituyen nuevas piezas que nos ayudan a completar el puzzle de la sociedad de esta época, pues ofrecen, en suma, interesantes detalles acerca de las escenas cotidianas de las vidas de estas mujeres: su papel dentro de la organización familiar, su ubicación en la intimidad de sus espacios domésticos, sus vestimentas, su participación en las relaciones internacionales del Reino meriní, etc.

La importancia y el peso del matriarcado en algunos ámbitos de la sociedad meriní son evidenciados en ciertos ejemplos onomásticos citados en el Musnad, donde algunos personajes aparecen referidos por algún ascendente femenino; este fenómeno excepcional de filiación matrilineal responde, en opinión de Helena de Felipe $^{87}$, a la importancia y mayor notabilidad de la familia materna del personaje en cuestión. Sirvan de ejemplo los casos de dos ilustres visires beréberes del emir Abū 1-Ḥasan: Abū Muŷāhid Gāzī b. al-Ka's, quien a decir del texto portaba como sobrenombre "el nombre de su madre" (ummu-hu) y Abū l-Ḥarakāt "Askar b. Țalha b. Tāḥadrīt, nombre este último correspondiente al de su abuela paterna (ism ŷaddatihi li-abi-hi)", como aclara el autor del Musnad ${ }^{88}$.

Existen llamativas referencias de índole femenina en distintas noticias recogidas por esta fuente con Tremecén como telón de fondo. Para empezar, el Musnad nos describe la celebración de la toma de esta ciudad por parte del emir Abū 1-Ḥasan "como festejo de bodas y de alegría" $"{ }^{89}$, haciendo uso de una metáfora nupcial muy habitual en las crónicas árabes medievales en las que las ciudades son en ocasiones descritas como novias en el momento de sus esponsales. Relata la misma fuente que, cuando este sultán conquistó dicha ciudad, suprimió el cuarto de todas las tasas así como distintos impuestos existentes en dicha urbe, eliminando también aquellas prácticas arancelarias llevadas a cabo por cristianos y judíos que resultaban humillantespara la población musulmana. Cita Ibn Marzūq al respecto cómo era costumbre que un cristiano, judío o extranjero registrase, de pies a cabeza, a cada musulmán que llegaba a Tremecén con el objeto de evitar que introdujese de incógnito mercancías gravadas con algún impuesto; y cómo por este procedimiento

\footnotetext{
${ }^{87}$ FELIPE, Helena de, Identidad y onomástica de los Berérebes en al-Andalus, Madrid, 1997, 70.

${ }^{88}$ IBN MARZŪQ, Muhammad, Musnad, 362; trad. VIGUERA, 299.

${ }^{89}$ IBN MARZŪQ, Muhammad, Musnad, 171.
} 
pasaban también las mujeres musulmanas, pues de ellas "se encargaban mujeres judías (al-yahüdiyyāt) que las registraban y les palpaban hasta el cuerpo, lo cual resulta una fealdad e ignominia evidentes. Esto sucedía en Tremecén y su provincia, y no existe en ninguno de los países que conozco [cosa] igual o parecida, sino lo que he visto en Alejandría - ique Dios la proteja y la libre de esto y multiplique el premio de quien quite aquello por entero! $--^{90}$.

Existe otra anécdota de contenido femenino, extraída del capítulo primero del Musnad, que tiene a la ciudad de Tremecén como escenario y con la que Ibn Marzūq ilustra la bondad de carácter y la perfección de apariencia de Abū 1-Ḥasan. Refiere este relato que cuando dicho emir estaba pasando revista a las tropas en Tremecén, reparó en la marlota que llevaba un miembro de los Banū 'Askar y cuyo origen era un vestido femenino $\left(\underline{t} a w b^{a n} n i s \bar{a}^{\prime} i y y^{a n}\right)$ de tela de zardajān, que le había sido regalado por el padre de Abū l-Ḥasan. Explica Ibn Marzūq al respecto que tal prenda "no se distinguía [de la marlota] más que los bordes, a causa de los apliques que ya tenía"

Otras anécdotas están referidas a las mujeres del entorno del propio Ibn Marzūq. Así, en el epílogo, sin duda el apartado más autobiográfico de toda la obra, el autor justifica cómo su relación personal con el sultán Abū l-Ḥasan era un asunto que le venía de familia: no sólo se remontaba a la generación de su abuelo materno, llamado Abū Ishạāq Ibrāhīm b. Yajlaf al-Tanasī, sino que se mantuvo durante la de su padre y tío paterno, llamados respectivamente Aḥmad (m. 741/1340) y Muhammad (m. dp. 747/1346) $)^{92}$, quienes eran también asiduos de la corte fezí y tenían bastante trato con el sultán Abū Sa ‘̄ìd, padre de Abū 1-Hasan. De hecho, cuando el emir Abū Ya qūo Yūsuf (685-706/1286-1306) accedió al poder, decidió casar al padre de Ibn Marzūq con la madre de éste, una mujer llamada Jadîya que era hija del Abū 1Ḥasan al-Tanasī. A partir de ahí, el emir "se encargó de velar por la situación de ambos", estableciendo a Aḥmad, el padre de Ibn Marzūq, en Tremecén la Nueva. Desde allí iría como embajador a la corte de Fez en cierta ocasión, en que el emir Abū Sa îd le preguntó "si había tenido hijos [de su casamiento] con aquella [mujer]", hablándole de su hijo Ibn Marzūq. Pero Aḥmad no fallecería en Tremecén, sino en La Meca, aunque ansiando desde la lejanía que Dios cubriese con su protección "a niños y mujeres" hasta que volviese a recuperar la ciudad el sultán Abū l-Ḥasan".

En esta sección tan personal da también una sutil pincelada Ibn Marzūq acerca de la que fue su esposa, cuyo nombre, como era de esperar, no revela, limitándose tan sólo a mencionar algún detalle de su actitud hacia ella. Por esta referencia indirecta sabemos que su mujer era hija del alfaquí Abū 'Abd Allāh Ibn 'Imrān, y que entre suegro y yerno había las discordancias propias de los parientes políticos. Ello

\footnotetext{
${ }^{90}$ IBN MARZŪQ, Muhammad, Musnad, 285; trad. VIGUERA, 236.

${ }^{91}$ IBN MARZŪQ, Muḥammad, Musnad, 125; trad. VIGUERA, 109.

${ }^{92}$ VIGUERA MOLÍNS, Ma Jesús, El Musnad, 12.

${ }^{93}$ IBN MARZŪQ, Muhammad, Musnad, 479; trad. VIGUERA, 397-398.
} 
ocurría, por ejemplo, ante el hecho de que Ibn Marzūq procuraba llevar siempre a su esposa consigo a dondequiera que él iba, algo en lo que ella estaba conforme aunque no tanto su suegro, que se oponía y se lamentaba de ello ante algunos habitantes de $\mathrm{Fez}^{94}$.

Sin abandonar todavía la vida de Ibn Marzūq, mencionaremos algunos datos de interés presentes en su obra sobre servidoras y esclavas con las que él tuvo trato directo. Relata el autor que, en cierta ocasión que se puso enfermo en la Manșūra de Tremecén, el emir Abū 1-Ḥasan le "envió a una de las servidoras (mušāwiriyyāt) de su casa y de las más próximas a él, llamada Burayka", quien le llevó "en una bandeja una gallina asada", pidiéndole que se tomara todo el alimento para que el emir la recompensase por haber velado bien por su salud ${ }^{95}$. En otro relato de esta obra, lamenta el autor cómo se le murió en Túnez "una esclava (ŷâriya) a quien mucho consideraba", pérdida que le dolió profundamente; y que, estando sentado un día con el sultán "en la habitación que da a los jardines de su residencia", entró en la alcoba un hombre de confianza de éste, al que el emir le preguntó: "«¿Cómo está la esclava abisinia (al-ŷāriya al-ḥabašiyya) que dejó [a su muerte] 'Abd al-Muhaymin, que nosotros hemos comprado de su herencia y que ha sido criada por Ibn Jaldūn?» Le respondió: «Señor mío, es un dechado de perfecciones y si la da nuestro señor a alguno de nuestros hijos (es decir, de los hijos de Abū 1-Ḥasan), ¡estupendo!, pero si no, no debe salir de la casa de nuestro señor»". Ante lo cual, el emir, que tenía a Ibn Marzūq en tanta consideración como a sus propios vástagos, decidió cederle esta virtuosa esclava ${ }^{96}$.

Otro conjunto de referencias de índole femenino, inserto en esta obra, nos sitúa a la mujer meriní en sus espacios domésticos, bien sencillos bien cortesanos. Mencionemos en este sentido una anécdota, presenciada por Ibn Marzūq en el Consejo del Mexuar de este emir en Marraquech, a donde acudió, por iniciativa del propio Abū l-Ḥasan, un anciano y virtuoso šayj llamado Abū Ŷa far b. Fulān b. Yahyà b. al-Manșur, que había estado relacionado con los últimos soberanos Almohades. El emir meriní se interesó por su bienestar y por su situación económica, llegando a vestirlo con sus propias ropas reales. Como quiera que Abū l-Hasan le preguntase si tenía familia, a lo que el anciano contestó: "Una anciana ( 'âȳuz) que me cuida", el soberano ordenó a uno de sus esclavos que fuese a buscarla, tras lo cual apareció ella ante el šayj, vestida con trajes [de las mujeres] de la familia real", siendo ambos honrados con una magnífica casa que había sido comprada para él, y que contenía todos los enseres y comodidades posibles ${ }^{97}$. Una muestra de la extrema generosidad que, en suma, demostraba este soberano hacia las personas dignas de consideraciónindependientemente de su género y del linaje al que hubiesen sido leales.

\footnotetext{
${ }^{94}$ IBN MARZŪQ, Muhammad, Musnad, 495; trad. VIGUERA, 410.

${ }^{95}$ IBN MARZŪQ, Muhammad, Musnad, 491; trad. VIGUERA, 406.

${ }^{96}$ IBN MARZŪQ, Muhammad, Musnad, 489; trad. VIGUERA, 405.

${ }^{97}$ IBN MARZŪQ, Muḥammad, Musnad, 337-340; trad. VIGUERA, 278-281.
} 
Similar es otra historia, recogida en el mismo apartado, sobre un hombre virtuoso llamado 'Ūsà b. 'Abd al-'Azīz b. Yallabajt al-Ŷazūlī, a quien Abū 1-Ḥasan también requirió ante su presencia.Y una vez hubo acudido, traído por unos mensajeros del emir, éste le entrevistó y le ordenó que se despojara de la capa remendada de lana que llevaba para ponerse "un alquicel nuevo que se le había preparado (...), colmándolo a continuación de lujos y bienes entre los que figuraban "servidores y esclavas" $"$, a pesar de su humilde y piadosa condición.

El último relato de este capítulo en el que la mujer está presente es, aún, más hermoso que los anteriores, siendo sus protagonistas un califa almohade y un hombre andalusí llamado Abū Marwān b. Zuhr. Cuenta esta anécdota que, estando este último en la corte mu'miní, se agravó la nostalgia que sentía por su hijo, al que había dejado en al-Andalus, ante lo cual el soberano almohade ordenó a su servidor Ibn Maymūn que fletase desde Salé dos barcos a Sevilla para traer a la familia de Ibn Zuhr al Magreb con todas las atenciones. Ibn Maymūn cumplió la orden real pero cuando Ibn Zuhr vio a su hijo no mostró demasiado alborozo, explicando al extrañado soberano que "lo hubiera querido en los brazos de su madre ( $f \grave{i} \underline{\operatorname{dir}} \bar{a}$ ' ummi-hi)". Tras lo cual condujo el califa a Ibn Zuhr una lujosa vivienda fuera del alcázar, donde este vio al entrar a su mujer en la puerta con su hijo en sus brazos, vestida con vestidos regios" ${ }^{\prime 9}$. Una historia que, sin duda, muestra el peso desempeñado por la mujer en la familia, tanto en su papel de esposa como en el de madre, y la consideración debida a ella por ambas razones.

Compasión fue lo que sintió, asimismo, Abū 1-Ḥasan por otra mujer (imrä't min $a l-b \bar{a}$ iyya $t$ ) que se presentó ante él, pues le había vendido al emir parte del patio de la mezquita de al- 'Ubbād de Tremecén y se lamentaba ante el sultán de las dificultades para vivir que tal cesión le había acarreado; una situación ante la que Abū l-Ḥasan recapacitó, resolviendo "construir, en la parte de patio que quedaba, una casa con viviendas suficientes para toda aquella gente que había sido expropiada por dinero" 100 .

Elijamos, para finalizar, otros detalles anecdóticos de muy distinta naturaleza en la que se advierte la consideración de la mujer en las relaciones políticas e, incluso, diplomáticas establecidas por el Reino meriní en tiempos del emir Abū 1-Ḥasan. Un detalle que llama la atención al respecto es el hecho de que la casa real meriní contara con una "mujer de confianza" (tiqa), "la señora (al-ḥurra) Fāṭima bint Sa '̄id", quien se encargó de poner a disposición de Ibn Marzūq todo lo que había en las residencias reales meriníes de Tremecén cuando tuvo que viajar a dicha ciudad, para que no se sintiera allí como un extranjero ${ }^{101}$. Sorprendente resulta, por último, la inclusión de féminas de la realeza cristiana en los cumplidos diplomáticos del emir Abū 1-Ḥasan, así como la implicación de estas reinas consortes en tales redes políti-

\footnotetext{
${ }^{98}$ IBN MARZŪQ, Muhammad, Musnad, 341-342; trad. VIGUERA, 281-283.

${ }^{99}$ IBN MARZŪQ, Muhammad, Musnad, 343-347; trad. VIGUERA, 284-287.

${ }^{100}$ IBN MARZŪQ, Muhammad, Musnad, 192; trad. VIGUERA, 162.

${ }^{101}$ IBN MARZŪQ, Muḥammad, Musnad, 487; trad. VIGUERA, 403.
} 
cas. Y es que, según el Musnad, el emir mencionado enviaba regalos con frecuencia al rey Alfonso XI de Castilla (1312-1350), unos detalles que se hacían extensivos también a la mujer de aquél, María de Portugal (m. 1357), pues consta que "también envió [Abū 1-Ḥasan] un regalo a la esposa del [rey] cristiano (li-zawyat al-nașrāñ̄), cuando ésta le favoreció a [Abū l-Hasan] con un servicio y con un consejo, y fue un regalo inconmensurable" ${ }^{102}$.

\section{CONCLUSIÓN}

Los ejemplos ofrecidos y analizados a lo largo de este trabajo no pretenden sino constatar un hecho bastante evidente: la presencia, de uno u otro modo, de la mujer en el Musnad de Ibn Marzūq y, por extensión, en la sociedad meriní de la época del emir Abū l-Hasan, así como su importancia. Sea bien como reflejo real bien como pose historiográfica, lo cierto es que esta fuente aporta datos de gran relevancia acerca de las actividades desempeñadas por las féminas, fundamentalmente magrebíes, en distintas esferas (histórica, política, genealógica, antropológica, familiar, religiosa, social e, incluso, moral), según se desprende del amplio abanico de anécdotas transmitidas en esta obra. Igualmente, el Musnad permite situar en su discurso aquellos ámbitos de la civilización islámica medieval en los que la presencia femenina se hacía especialmente visible: desde los primeros pasos de la historia del Islam, la organización tribal propiamente beréber, la base misma de la genealogía del individuo, la cómoda vida cortesana, la sencillez de la vida popular, la intimidad del ámbito familiar, la existencia obligada de la esclavitud y la servidumbre, la estrechez del vínculo materno-filial, la diversidad de posibilidades en la elección de féminas con fines conyugales, hasta incluso la sorprendente intrusión de mujeres de otros signos religiosos -judíos y cristianos- en la administración islámica.

Tal vez la inclusión de este misceláneo elenco de anécdotas femeninas en dicha obra responda a la visión más matriarcal que la cultura beréber tenía de la sociedad y de la familia, a pesar de la "patriarcalización" que supuso la influencia en este orden social de la cultura islámica adoptada. Sea como fuere, lo cierto es que el Musnad nos da suficientes muestras para erigirse en un reconocimiento explícito a la importancia de la mujer en la sociedad medieval, permitiéndonos acentuar con nuevos datos el importante papel que ésta desempeñó en la misma.

${ }^{102}$ IBN MARZŪQ, Muhammad, Musnad, 454; trad. VIGUERA, 375. 